\title{
Grounding Pancasila Values as Nusantara Character Building
}

\author{
Sahala Martua Solin', Lisnawati Hasugian²
}

Sekolah Tinggi Pariwisata Bandung, Indonesia ${ }^{1}$, Sekolah Tinggi Teologi Kalam Mulia, Bandung, Indonesia ${ }^{2}$

sahalasolin@gmail.com¹, lisnahasugian11@gmail.com²

Article History

accepted 23/03/2021

approved 10/04/2021

published 20/04/2021

\begin{abstract}
Indonesia is increasingly showing a more civilized humanity through incessant social practices in times of pandemic pressure and natural disasters. Various difficulties experienced by all levels of society have raised the attention of others to help help in locations affected by the economic crisis and losing their jobs. Almost all lines are trying to push the values of Pancasila by the impulse of the cultural conscience of the people's wisdom. It seems that the movement of the ideological spirit by the residents has not yet been realized that the character building of Pancasila values is moving. Therefore, a phenomenological research is needed on the implementation of Pancasila values from government, institutional and community activities as character building. The purpose of this research is to prove that the values of Pancasila are the character of the Nation which is a reflection of National resilience. The research method used is the method of interview and observation to determine the qualitative awareness of understanding the values and their implementation that is being carried out by the community. The findings obtained are that the local community carries out social service activities to reduce the burden of food, clothing, shelter and economic congestion in the family to create psychological and life resilience. The second finding is that the public is increasingly aware of the power of citizen unity driven by the spirit of the Pancasila ideology among pluralist communities. From these findings, it is concluded that the values of Pancasila must be grounded through community coaching / learning activities with the colors of the characters and local wisdom according to the culture of the environment.
\end{abstract}

Keywords: Pancasila values, character building, local wisdom, culture

Abstrak

Indonesia semakin menunjukkan kemanusiaan yang lebih beradab melalui gencarnya praktekpraktek sosial dimasa tekanan yang masih pandemik dan bencana alam. Berbagai kesulitan yang dialami seluruh lapisan masyarakat, muncullah perhatian sesama untuk tolong menolong dilokasi-lokasi terdampak krisis ekonomi dan kehilangan pekerjaan. Hampir semua lini berusaha melakukan gerekan nilai-nilai Pancasila oleh dorongan hati nurani budaya kearifan warga. Pergerakan ruh idiologi tersebut oleh warga sepertinya belum disadari bahwa sedang bergeraknya pembangunan karakter nilai-nilai Pancasila. Oleh karena itu, diperlukan penelitian fenomenologi pengimplementasian nilai-nilai Pancasila dari kegiatan pemerintah, lembaga dan masayarakat sebagai character building. Tujuan penelitian ini membuktikan bahwa nilai-nilai Pancasila adalah karakter Bangsa yang menjadi cerminan ketahanan Nasional. Metode penelitian yang digunakan adalah metode wawancara dan observasi untuk menentukan kualitatif kesadaran pemahaman nilai-nilai dan implementasinya yang sedang dilakukan masyarakat. Temuan yang didapat adalah bahwa masyarakat sekitar melakukan kegiatan bakti sosial mengurangi beban krisis pangan, sandang, papan dan kemacetan ekonomi keluarga untuk menciptakan ketahanan psikologi dan kehidupan. Temuan kedua bahwa masyarakat semakin menyadari kekuatan kesatuan warga yang digerakkan ruh idiologi Pancasila diantara masyarakat pluralis. Dari hasil temuan ini, disimpulkan bahwa nilai-nilai Pancasila harus dibumikan melalui kegiatan-kegiatan pembinaan/ pembelajaran masyarakat dengan warna karakter dan kearifan lokal sesuai budaya lingkungannya.

Kata kunci : nilai-nilai Pancasila, character building, kearifan lokal, budaya

Social, Humanities, and Education Studies (SHEs): Conference Series https://jurnal.uns.ac.id/shes

p-ISSN 2620-9284 e-ISSN 2620-9292 


\section{PENDAHULUAN}

Karakter adalah cara berpikir dan berperilaku menunjukkan ciri khas setiap individu dalam hidup bersama dan bekerjasama ditengah lingkungan keluarga, masyarakat, bangsa, dan negara (Suyatno, 2010). Nilai adalah konsep, suatu sistem pembentukan mental yang dirumuskan dari tingkah laku manusia dan menjadi standar mengatur tindakan. (Clyde Kluckhohn, 1951). Kedua kata diatas difungsikan dalam artikel untuk memberikan jalan masuk memahami bagaimankah nilai Pancasila dapat membangun alas atau dasar yang menentukan berapa berat yang mampu ditopang oleh warga sebagai kesaksian idiologi bangsa. David McLendon mengatakan, jika karakter anda seukuran tusuk gigi, anda hnya mampu menopang sehelai perangko, namun jika karakter anda setebal pilar, anda dapat menopang atap bangunan (David McLendon, 2014). Bagaimanakah nilai Pancasila itu dipahami bergantung dari pada dalamnya pengertian nilai tersebut pada seseorang. E. Imam Maksudi dalam artikelnya yang diceramhkan pada PUP TAPLAY, 2020, menyebutkan bahwa nilai dapat diartikan sebagai sesuatu tentang yang baik atau yang buruk. Ditambahkan oleh Perry (1954) mengatakan bahwa nilai adalah segala sesuatu yang menarik bagi manusia sebagai subjek. Oleh karena itu, bagaimana dapat terbentuknya nilai-nilai Pancasila sebagai pemmbentuk karakter yang menarik bagi warga negara.

Masyarakat Indonesia pada masa pandemi Covid 19 berdampak pengurangan aktivitas kerja dan kemacetan perekonomian, juga bahkan tambahnya keadaan beberapa daerah yang terkena dampak bencana alam, muncullah gerakan-gerekan yang signifikan dari implementasi kemanusiaan yang semakin lebih beradab melalui kegiatan bakti sosial dan peran perhatian keadilan sosial bermasyarakat. Berbagai kesulitan yang dialami seluruh lapisan masyarakat oleh karena dampak dari pandemi tersebut, membutuhkan hati nurani yang tenang dan mendapat solusi bersama antara masayarakat dan pemerintah dengan berbagai cara sedang berlangsung. Baik dari pemerintah sendiri berusaha melakukan bentuk-bentuk penanggulangan dimulai dari pengurangan pandemi, menyiapkan penanggulangan yang terdampak dan mencari serta menyalurkan vaksinasi hingga saat ini. Demikian juga halnya, bahwa masyarakat ikut serta menjaga diri dan mematuhi protokol kesehatan serta menunggu giliran vaksinasi. Semua hal ini dilakukan bersama untuk memulihkan keadaan bagsa menjadi normal demi terwujudnya ketahanan nasional. Sirkuliasi situasi masayarakat dan pemerintah yang sedang berlangsung ini mendapat perhatian peneliti oleh karena teater yang sedang/telah terjadi dimana sesama masyarakat sedang melakukan gerakan tolong menolong dilokasi-lokasi terdampak krisis ekonomi dan kehilangan pekerjaan tersebut. Hampir semua lini berusaha melakukan gerakan-gerakan gotong royong yang adalah sebagai wujud nilai-nilai Pancasila. Gerakan hati dan raga dari masyarakat lokal itu didorong oleh hati nurani budaya kearifan lokal. Baik dalam lingkungan perkotaan dan juga dalam lingkungan pedesaan. Menyampingkan dari makna dan asal muasal munculkan gerakan nilai-nilai Pancasila ini terjadi, hanya semata bahwa keadaan yang sedang krisis telah menuntut dari identitas kemanusiaan sebagai ciptaan Allah muncul sendirinya. Sehingga hanya melihat dari hasil dan tujuan perbuatan tersebut adalah mendapat solusi dan kebaikan bersama. Pergerakan tersebut adalah pergerakan dari ruh idiologi bangsa yang berbuah oleh warga bersumber dari nilai-nilai Pancasila yang sudah lama terpatri pada warganegara Indonesia. Namun kelihatannya bahwa gerakan ini hanya dinikmati sebagai kehidupan yang semestinya terjadi sedemikian rupa diatara sesama. Padahal bahwa gerakan ini tidaklah seketika muncul jika ada tekanan saja, tetapi suatu ruh hidup dalam kenegaraan yang telah dimilikinya sejak lama. Dengan tidak disadarinya oleh sebahagian besar masyarakat tentang pemaknaan atau asal muasal dari gerakan nilainilai tersebut, maka diperlukan suatu penelitian fenomenologi terjadinya pengimplementasian nilai-nilai Pancasila, baik dari kegiatan pemerintah, lembaga dan masayarakat untuk terarahkannya menjadi suatu betuk character building bagi warga 
negara. Sedangkan tujuan penelitian ini membuktikan bahwa nilai-nilai Pancasila adalah karakter Bangsa yang menjadi cerminan ketahanan Nasional, yang menguatkan pemerintahan dan lingkungan masyarakat diseluruh Indonesia.

\section{METODE}

Metode penelitian yang dilakukan adalah penelitian kualitatif, menegaskan ciri-ciri yang dimiliki "menggunakan analisis data secara induktif" (Melong, 2002). Ciri lainnya adalah manusia sebagai subjek penelitian, dan sasaran penelitian mengarah pada usaha menemukan teori dasar fenomenologi, bersifat deskripsi, lebih mementingkan proses dari pada hasil, kemudian untuk keabsahan data akan membatasi studi. Rancangan penelitian (yang bersifat sementara), dan hasil penelitian serta subjek penelitian (Sugiyono, 2006). Menggunakan metode kualitatif untuk mendapatkan data dalam situasi yang wajar dan data yang dikumpulkan pada umumnya bersifat kualitatif (Usman \& Akbar. 2001).

\section{HASIL DAN PEMBAHASAN \\ Karateristik Nilai-Nilai Pancasila sebagai Idiologi Negara}

Pancasila sebagai dasar negara mempunyai kedudukan mejadi norma objektif dan norma tertinggi di dalam negara serta sebagai sumber dari segala sumber hukum dan sumber tertib hukum negara Republik Indonesia. Hal ini sesuai dengan Tap MPRS No. XX/MPR/1966 jo Tap MPR No. V/MPR/1973 jo Tap MPR No. IX/MPR/1978, selanjutnya dipertegas lagi mengenai kedudukan Pancasila sebagai dasar negara berdasarkan Tap MPR No. XVII/MPR/1998 yang kemudian dicabut dengan Tap MPR No. II/MPR/2000. Dalam Tap MPR No. II/MPR/2000 tentang Sumber Hukum disebutkan bahwa Pancasila dan batang Tubuh UUD 1945 (setelah diamandemen dibaca pasal-pasal) menjadi Sumber Hukum Dasar Nasional, dan dengan ditetapkannya ketetapan ini maka Pancasila tidak lagi sebagai sumber dari segala sumber hukum melainkan menjadi Sumber Hukum Dasar Negara (Tim Pokja bahan Ajar SBS. Pancasila. 2020).

Idiologi adalah kompleks pengetahuan dan nilai yang secara keseluruhan menjadi landasan bagi seseorang (atau masyarakat) untuk memahami jagat raya dan bumi seisinya serta menentukan sikap dasar untuk mengolahnya (Tim Pokja bahan Ajar SBS. Pancasila. 2020:37). Berdasarkan pemahaman yang dipaparkan diatas, setiap orang yang memiliki kemampuan untuk menafsirkan apa yang dilihatnya yang benar atau tidak benar dan yang baik atau tidak baik. Sehingga memperlihatkan cara hidupnya yang sesuai dengan apa yang telah ditangkapnya. Dengan demikian, terbentuklah dunia kehidupan sosialnya di masayarakat dengan sistem dan struktur berdasarkan orientasi idiologinya. Walaupun idiologi itu sendiri bukanlah sesuatu yang berdiri sendiri yang lepas dari kenyataan hidup masyarakat, namun adalah produk kebudayaan suatu masyarakat yang juga merupakan manisfestasi kebiasaan sosial. Pada hakikatnya bahwa idiologi tidak lain adalah hasil refeksi manusia berkat kemampuannya mengadakan distansi terhadap dunia kehidupannya yang mencerminkan cara berpikir masyarakat, tetapi juga membentuk masyarakat menuju cita-citanya.

Idiologi merupakan perwujudan karakter yang membawa keyakinan dan komitmen untuk diwujudkannya menjadi ketentuan-ketentuan normatif yang harus diatati dalam hidup bermasyarakat. Dengan demikian, idiologi berfungsi untuk; menstruktur kognitif, menegaskan orientasi dasar, menuntun pada norma-norma kehidupa, menjadikan bekal dan jalan menemukan identitasnya, sebagai pendorong kekuatan, dan pendidik bagi diri sendiri dan bermasyarakat untuk memahami, menghayati, dan mempolakan tingkah lakunya sesuai dengan orientasi dan normanorma yang terkandung didalamnya.

Sebagai idiologi nasional, Pancasila berfungsi menggerakkan masyarakat untuk membangun bangsa dengan usaha-usaha yang meliputi semua bidang kehidupan. Pancasila yang pada dasarnya menampilkan nilai-nilai universal, 
berwawasan yang integral-integratif dan juga relevan menjadi idiologi modern saat ini. Pancasila dilahirkan dalam budaya dan peradapan timur sangat menjunjung tinggi peran religiusitas yang masih dipertahankan sekarang ini. Oleh karena itu, Pancasila menawarkan solusi terhadap krisis dunia dengan menjada keutuhan manusia sebagai pribadi di tengah keramaian peradaban dalam proses alienasi kultur.

Sebagaimana yang terlihat kondisi masyarakat sejak semula sudah majemuk, yang bersifat multietnis, multireligius, dan multiidiologi. Kemajemukan tersebut menunjukkan adanya berbagai unsur yang saling berinteraksi, seperti perwujudan sosial perkotaan, pedesaan dan bahkan antar warga negara asing di Indonesia. Dengan adanya Pancasila sebagai idiologi negara, mendapat kesempatan bagi warganegara untuk mengusahakan pengimplementasian nilai-nilai Pancasila sebagai bentuk proses hubungan sosial agar berjalan secara sentripetal mewujudkan ketahanan nasional.

Pancasila sebagai idiologi negara memiliki karakteristik nilai-nilai yang dapat membentuk warganegara yang semakin beradap tinggi. Oleh karena itu, langkahlangkah untuk membumikan nilai-nilai Pancasila sebagai idiologi negara harus masuk pada ruang pegawai pemerintahan yang lebih dalam, lingkungan guru-guru dan dosen secara keseluruhan, dan bagi masyarakat dari berbagai profesi, seperti pengusaha, pedagang, petani, nelayan, dan lainnya. Pembumiaan yang semestinya terjadi sejak dini dengan cara menyediakan pembekalan-pembekalan yang bersifat teori/seminar atau praktis dalam lingkungannya masing-masing.

Dapa diperhatikan suatu praktek lapangan tentang pembekalan kepegawaian untuk mendalami pentingnya peran dari idiologi negara bagi kebutuhan pelayanan masayarakat sangat minim dan hampir tidak ada dikarenakan tugas yang sudah menanti. Berkaca dari minimnya pemahaman idiologi dari kalangan kepegawaian, bagaimana dengan presentasi masyarakat untuk mendapat pembekalan pemahaman idiologi negara tersebut. Tentu angka presentasi yang dimaksud disini tidak dapat dibuktikan penulis, namun dapat diketahui bagaiman proses bernegara dan bermasayarakat selama ini, yang telah terjadi dan masih sangat kurang implementasinya, seperti pemerintahan daerah telah melakukan pembekalan kepada anggotanya jauh dari presentasi jumlah pegawai yang semertinya wajib mengikuti pendidikan tentang pemahaman idiologi negara secara khusus. Hal ini memang masih harus memerlukan penlitian langsung kepada instansi-instansi pemerintahan, untuk mendapatkan data yang lebih akurat. Namun, tentu akhir tujuan pentingnya pembumian nilai-nilai Pancasila sangat memerlukan perhatian dari semua lini di negeri ini, dimulai dari instansi atau lembaga-lembaga pemerintahan, lembaga-lembaga pendidikan, para profesional dan masayarakat.

\section{Karateristik Nilai-Nilai Pancasila bagi Warganegara Indonesia}

Pancasila dipandang sebagai seperangkat nilai, yang terdiri atas lima nilai yang menjadi kebutuhan yang melekat. Nilai-nilai yang dimaksud merupakan wahana untuk menyelaraskan dan memadukan segala bentuk perbedaan yang ada, mendorong serta menguatkan rasa kepedulian dan kerjasama untuk mengatasi tantangan dan kesulitan yang ada. Kesemuanya ini merupakan faktor-faktor utama pembentukan semangat persatuan demi memelihara kesatuan bangsa dan negara republik Indonesia. Nilai-nilai kebangsaan yang dimaksud adalah nilai religius, nilai kekeluargaan, nilai keselarasan, nilai kerakyatan, dan nilai keadilan.

Nilai religius, mengandung makna ketakwaan kepada Tuhan Yang Maha Kuasa, yang menciptakan alam semesta beserta isinya. Peran pemahaman nilai religius ini sangat besar menciptakan ketakwaan kepada Tuhan Yang Maha Esa untuk pembentukan karakter warganegara. Arahnya adalah membawa setiap warga untuk beragama dan takwa kepada Tuhan yang dipercayainya. Karena dasar seseorang mempunyai kepercayaan yang dari Tuhan tentu mengajarkan kebaikan dihadapan Tuhan dan sesamanya. Hal inilah memberikan kebebasan beragama yang mutlak 
dengan keragamaannya dan harmonis, berimplikasi kepada sikap hidup yang rendah hati, menghargai keberadaan orang lain tanpa memandang asal-usul, warna kulit atau pun anutan agama dan kepercayaan, serta memiliki tanggungjawab sosial yang tinggi. Nilai religius ini juga menunjukkan adanya kesadaran dan tanggung jawab untuk memelihara alam sekitar sebagai wujud rasa bersyukur atas karunia Sang Pencipta.

Nilai ini terlihat berjalan baik sejak pandemi covid 19 berlangsung hingga sekarang. Hal-hal yang telah terjadi pada masa pandemi adalah adanya anjuran pemerintah untuk berdoa setiap keluarga dari rumahnya masing-masing, karena bangsa sangat memerlukan doa-doa rakyatnya. Kemudian, sendirinya masyarakat juga mendoakan pemerintahnya karena kepentingan dari kesejahteraan rakyat yang diusahakan pemerintah. Tentu inilah yang disebut bagaimana nilai-nilai Pancasila bagi warganegara menjadi wadah mempersatukan bangsa sebagai ciptaan Tuhan untuk mewujudkan ketahanan nasional.

Nilai kekeluargaan, yang menunjukkan kesediaan dan kesadaran setiap insan dan warga negara Indonesia untuk menempatkan dirinya sebagai bagian yang tak terpisahkan dari sebuah keluarga besar, bangsa Indonesia. penempatan nilai kekeluargaan inilah menjadi dasar untuk mewujudkan nilai-nilai kebaikan yang beretika dan berkearifan loka, sebagai kekuatan membangun dan menjaga keselarasan (harmoni) hubungan antara elemen masyarakat, untuk mampu maju bersama mencapai tujuan nasional. Nilai kekeluargaan juga akan mampu menghadapi bersama kesulitan-kesulitan dan tantangan bangsa serta menciptakan suasana masyarakat yang rukun, tentram dan damai.

Nilai kerakyatan, merupakan dasar bagi pengakuan terhadap rakyat Indonesia sebagai pemilik kedaulatan negara, untuk dapat menentukan masa depan kehidupan berbangsa dan bernegara. Dalam hal ini rakyat adalah subjek utama dalam setiap gerak pembangunan serta menjadi dasar orientasi pembembangan segenap potensi sumberdaya nasional. Nilai kerakyatan ini telah terwujud sejak lama, namun semakin terlihat ketika adanya tantangan, seperti masa pandemi covid 19 ini, bahkan juga pada masa vaksinasi sekarang, banyak kelompok organisasi masayarakat, kelompok tokoh agama, bahkan partai pun ikut berperan memberikan santunan dan usaha menjadi fasilitas dan penyumbang kebutuhan masayrakat dan terlaksananya vaksinasi.

Nilai keadilan, menunjukkan adanya kemauan dan semangat yang terwujud dari keutuhan sikap takwa kepada Tuhan yang berimplementasi pada keadailan sosial, semangat gotong royong, dan kemampuan menjaga keharmonisan diantara segenap elemen masyarakat. Keadilan ini juga terwujud dari pemerintah kepada masayarakat, sebagai contoh nyata, pada masa pandemi covid 19 ini, pemerintah memerikan insentif kepada pegawai dan karyawan swasta serta masyarakat. Bukti data yang ditemukan bahwa pemerintah juga memberikan berdasarkan kebutuhan dan yang sangat membutuhkan. Kisah seorang karayawan yang bergaji honor dari lembaga pemerintah, mendapat insentif dari dana bantuan koperasi, dana yang masuk ke rekening bulan september, kemudian dicairkan bulan november melalui bank BRI, namun ketika disediliki data dari penerima bantuan ini dan ditemukan memang mendapat gaji tetap honorer dari lembaga tersebut, dan dana bantuan Koperasi melalui Bank BRI tersebut di blokir oleh BRI, walaupun jumlah yang tertera masih tercatat di buku Bank BRI pemiliknya. Secara konsisten pemerintah memberikan bantuan yang benar-benar membutuhkan tentu dapat diterima, namun secara kebutuhan yang sangat diperlukan pada masa-masa sulit ini, insentif adalah jalan keluar bagi pegawai tersebut untuk melangsungkan kebaikan ekonominya. Ini adalah suatu progres yang positip, jika benar-benar menerapkan pemberian bantuan bagi masayarakat secara adil dan merata.

\section{Karateristik Nilai-Nilai Pancasila sebagai Character Building}

Nilai-nilai Pancasila adalah dasar pembentukan karakater Bangsa Indonesia, karena sudah memuat segala aspek budaya. Implementasi yang diharapkan adalah 
adanya upaya untuk menyesuaikan dengan kearifan lokal yang telah kuat dan dapat membangun setiap lingkungannya dalam prinsip-prinsip dasar karakter Pancasila. Nilai-nilai yang harus membumi bagi segala profesi dan status bagi warganegara. Tentu upaya dalam pembumian nilai-niai Pancasila tersebut memerlukan metode atau model yang sesuai dengan budaya setempat. Berbagai metode langkah pembumian pemahaman nilai-nilai akan digunakan dan berdasar pada teori-teori terdahulu untuk mencapai tujuan dan capaian pembumian pelajaran nilai-nilai tersebut.

Nilai-nilai mungkin lebih efektif diajarkan dalam situasi yang kooperatif dari pada dalam situasi kompetitif atau individualistis (Johnson \& Johnson, 1989), karena individu cenderung untuk mengadopsi kebiasaan, nilai, sikap, perspektif, dan pola perilaku kelompok dari mana ia berasal atau ingin mejadi bagian dirinya (Johnson \& Johnson F., 2006) (Larry P. Nucci \& Darcia Narvaez, 2014:315)

Pembangunan karakter mempunyai nilai-nilai yang dipromosikan oleh interdependensi positif dan negatif, seperti berikut ini;

\begin{tabular}{lll}
\hline Nilai & Interaksi pertentangan & Interaksi promotif \\
Kesuksesan & Menang atas orang lain & Berusaha bersama \\
Saingan, halangan untuk & Teman, fasilitator, potensi \\
keberhasilan sendiri & Menghalangi orang lain, & Memfasilitasi, memberi \\
Usaha sendiri & menyebabkan kegagal & $\begin{array}{l}\text { sumbangsih untuk } \\
\text { keberhasilan orang lain }\end{array}$ \\
& orang lain & $\begin{array}{l}\text { Pengakuan dasar akan diri } \\
\text { dan orang lain }\end{array}$ \\
Harga diri & Tergantung pada & Intrinsik \\
Tugas & Ekstrinsik, alat untuk & Empati, kasih sayang \\
Penerimaan & menang & Penyesuaian \\
Perspektif & Tidak ada, atau sebagai layak \\
Agresi & Strategi & Persamaan hak, \\
Keadilan & Wajar & kebutuhan \\
& Ekuitas & \\
\hline
\end{tabular}

\section{Tabel 1.1}

Dalam konteks pendidikan, pengertian character building (membangun karakter) adalah suatu upaya atau proses yang dilakukan untuk memperlihatkan, menyatakan kesalahan, mengajarkan, memperbaiki, membina dan atau membentuk tabiat, watak, sifat kejiwaan, akhlak (budi pekerti), insan manusia (masyarakat) demi terwujudnya perangai dan tingkah laku yang baik kebenaran yang absolut.

Berhubungan dengan makna nilai dan nilai-nilai itu sendiri adalah bahwa karakter menjadi implementasi dari nilai-nilai yang telah dimiliki, oleh karakter akan terwujud sendirinya dan diperlihatkan kepada orang banyak. Tampak yang jelas akan terlihat oleh karakter itu sendiri secara konsisten dalam segala situasi. Dengan demikian , maka karakter (sering disebut watak) dapat dimengerti sebagai nilai-nilai yang sudah matang dan terinternalisasi dengan baik dalam diri seseorang, sudah menjadi bagian hidupnya sehari-hari, menjadi kecenderungan dan pilihan cara jalannya yang tetap, sehingga terwujudlah pengejawantahan atau ekspresi bagi sosial masayarakat.

Orang yang memiliki karakter bertindak menurut keyakinan-keyakinannya, bahkan mau mengambil sikap atau pendirian yang terkadang kurang disenangi orang lain, demi mempertahankan integritasnya. Tentu dapat dipahami bagaimana sikap pada pahlawan kemerdekaan Indonesia dahulu kala, bahwa mereka menolak kompromi dengan para penghyanat untuk memperjuangkan kemerdekaan dari penjajah. Sehingga dapat kita simpul bahwa karakter tampil dalam bentuk keyakinan 
dan ketaatan pada hati nurani. Inilah juga merupakan nilai yang harus dijunjung tinggi. Dan perihal yakin dan taat pada nurani ini sudah sedimikian tertanam dalam diri seseorang. Dengan prinsip ini, bahwa nilai-nilai Pancasila seharusnya menjadi nilainilai yang telah diajarkan dalam lingkungan pendidikan, dan menjadi nilai yang kuat bagi hati nurani setiap peserta didik. Namum melihat dari kondisi perubahan dari penguatan pendidikan tentang nilai-nilai Pancasila semakin kendur, maka memerlukan langkah cepat menggunakan metode pembinaan karakter.

Beberapa organisasi masyarakat, lembaga-lembaga swadaya masayarakat dan lembaga-lembaga pendidikan formal, non-formal dan informal, telah melakukan langkah pembumian nilai-nilai Pancasila ini. Tidak kalah juga di kalangan media sosial, juga ikut berperan untuk mengumandangkan prinsip-prinsip nilai-nilai Pancasila tersebut. Tentu masih panjang perjalanan untuk diupayakan dari berbagai pihak baik itu kalangan pemerintahan atau kaum profesional dan warga biasa, dapat maju dan mengusahakan bentuk-bentuk pembumian nilai-nilai Pancasila. Seperti halnya bahwa sikap yang baik dimulai dari lingkungan keluarga, kemudia bersama tetangga, serta komunitas-komunitas mengimplementasikan nilai-nilai tersebut.

\section{Keijakan Pembumian Nilai-Nilai Pancasila bagi Nusantara}

Gerakan jiwa dan spontanitas kegiatan masyarakat yang terlihat pada masa pandemi dan dampak bencana alam ini sangat signifikan pergerakannya. Hal ini adalah suatu kekuatan yang timbul dari ruh Pancasila dan telah saatnya muncul nilainilai Pancasila dalam lingkungan multikultural. Gerakan ini bukanlah tersembunyi tetapi didukung dengan perkembangan media teknologi saat ini memperlihatkan tumbuhnya sosial-citizen yang baik dan memerlukan pematangan. Pembumian nilai-nilai Pancasila ini, memang dimulai dari sponsorship pemerintah yang berani mempertahankan idiologi negara demi pembangunan dan ketahanan Nasional. Oleh karena itu, masayarakat sebagai subjek telah memperlihatkan respon tanggapan untuk menerima bagaimana implikasi dari nilai-nilai Pancasila tiba ke tempat lingkungan mereka. Masyarakat semakin memberikan pendengarannya tentang pemahaman nilai-nilai Pancasila sebagai jalan keluar keluh kesah pemerataan kesejahteraan rakyat. Tentu semua hal ada bidangnya, namun dengan respon masyarakat ingin mengetahui bagaimanakah pengimplementasian dari Pancasila itu, harus dipandang penting dan melakukan upaya pembumian nilai-nilai Pancasila, baik dalam bentuk pendidikan formal, non-formal, dan informal, atau pembinaan secara seminar atau pelatihan dan juga secara langsung kelingkungan masyarakat. Tentu langkah ini telah mendapat perhatian dari pemerintah pusat, sehingga mengharapkan dari kalangan organisasi masyarakat dan media sosial, dapat bekerjsama untuk mengupayakan pembumian nilai-nilai Pancasila.

Temuan penulisa dari beberapa lingkungan masyarakat dan organisasi masyarakat, sudah banyak melakukan langkha-langkah pembumian nilai-nilai Pancasila ini, seperti kegiatan-kegiatan karangtaruna yang bertemakan kebangsaan yang memuat nilai-nilai Pancasila. Demikian juga para LSM dan Lembaga Pendidikan, melakukan bentuk-bentuk pelatihan dan seminar kebangsaan yang muatannya adalah nilai-nilai Pancasila. Tidak ketinggalan juga bara pencita alam dan pegiat pariwisata, walaupun masih sebagian kecil, berupaya melakukan jelajah kebangsaan dengan muatan nilai-nilai Pancasila.

Temuan lainnya yang terjadi pada lingkungan pendidikan, yang dimulai dari pembinaan karakter berbasis kebangsaan di tingkat Sekolah Menengah Atas. Bagaimanakah langkah-langkah yang mereka lakukan? Sesuatu yang unik dan membangun, dengan cara memberikan suatu seminar penuh permainan bagi peserta dalam melakukan langsung dari prinsip-prinsip nilai-nilai Pancasila. Setiap peserta akan ikut kegiatan untuk mempraktekkan setiap point-point kelima sila Pancasila, dengan diintegrasikan praktek sederhana menggunakan alat bersimbolkan yang 
terdapat pada logo Pancasila. Kemudian memberikan makna dari setiap sila Pancasila untuk dihidupi dan dilakukan dalam dunia nyata lingkungan masyarakat

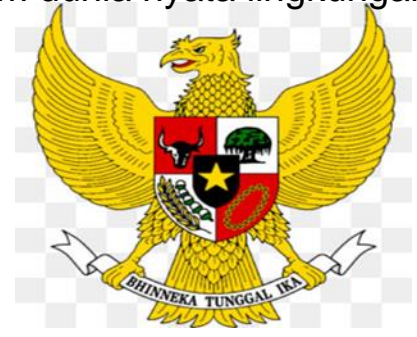

\section{Gambar 1. Logo Pancasila}

\section{SIMPULAN}

Pancasila adalah dasar idiologi Negara Kesatuan Republik Indonesia yang didukung dengan lengkapnya UUD 1945 untuk dilaksanakan oleh warga yang Bineka Tunggal Ika. Dengan dasar kekuatan inilahm bangsa Indonesia akan mampu menunjukkan ketahanan Nasional terhadap warganya atau juga bagi internasional. Langkah yang harus diupayakan dalam mempertahankan ketahanan nasional ini, maka dilakukan pembumian nilai-nilai Pancasila yang konsisten dan berselaras dengan kearifan lokal seluruh bangsa.

\section{DAFTAR PUSTAKA}

Suyanto. (2010). Model Pembinaan Pendidikan Karakter Di Lingkungan Sekolah. Jakarta: Dirjen Dikdasmen Direktorat Pendidikan Dasar dan Menengah Kementerian Pendidikan Nasional.

Kluckhohn. C. (1951). The Study of Culture. New York: Stanford University Press.

D. McClendon., Kuo J.C., \& Raley. (2014). Opportunities to Meet: Occupational Education and Marriage Formation in Young Adulthood. Journal of Demography, Vo. 51(4), 1319-44.

E. Imam Maksudi. (2020). Nilai-Nilai Kebangsaan Indonesia yang Bersumber dari Pancasila. Jakarta: Ceramah pada PUP TAPLAY

Tim Pokja Bahan Ajar SBS. Pancasila. (2020). Bidang Studi Empat Konsensus Dasar Negara - Sub Bidang Studi Pancasila. Jakarta Pusat: Lembaga Ketahanan Nasional Republik Indonesia. 